\title{
ARTICLE
}

\section{Mapping the Body's Movement}

Sarahleigh Castelyn

University of East London

Both geography and choreography are concerned with the movement of the body in space, and in the context of South Africa, the geography of apartheid might be understood as a legislative choreography. This article seeks to establish how aspects of geography studies could be employed as tools to analyse the choreography of a South African individual's embodied experience both on and off the theatre stage.

\section{Surveying choreography, geography and practice-based research}

"Choreography is the making of dance" (Butterworth \& Wildschut 2009: 1) and is concerned with the movement of the body. Geography studies focuses on the earth and the bodies that inhabit it (Nast \& Pile 1998: 1-19). Both dance and geography share the theme of the body's pathways through space; both are "very much in the business of representation" (Holloway \& Hubbard 2001: 168). I hold that dance is articulate about embodied spatial and geographical experience and that my practice-based research project, Body Maps: or how our garden grows (2006), uses movement as a form of embodied research into South Africa's recent and contemporary geographical experience of apartheid and post-apartheid realities. Estelle Barrett writes that "practice-led research is a new species of research" (2007: 1), and the "general feature of this research is that personal interest and experience, rather than object 'disinterested-ness' motivates the research process" (Barrett 2007: 5). Practice-based research in dance studies advances the relationship between the theory and practice of dance, and it is a "generative enquiry that draws on subjective, interdisciplinary and emergent methodologies" (2007: 1). In dance studies it models a wide range of creative strategies, such as choreography, partner work, velocity, composition, costuming, lighting, music, media, spoken text, and other theatrical elements, and it also is informed by other critical methodologies such as feminist studies, ethnography, poststructuralism, and other relevant "theoretical and philosophical paradigms" (Barrett 2007: 1). 
The title of my practice-based research project references Zbigniew Bialas's Mapping wild gardens: the symbolic conquest of South Africa (1997) in which Bialas studies the relationship between cartography, literary studies and South Africa. The book's title was a catalyst for my thinking through the connection between geography and my practice-based research project. Bialas highlights in his introduction that mapping is "liberally understood as almost any act of creating stereotypical representations" (1997: 13). The title of my practice-based research project suggests that our bodies undergo a type of mapping; for instance, they were stereotyped on the basis of the 'racial' ${ }^{1}$ categorisation of the apartheid state, or they are stereotyped because of their sex. This mapping/stereotyping of an individual's body remains evident in contemporary South Africa and is often employed for political purposes. The project's subtitle - 'or how our garden grows' - references colonial conquering of territory and therefore taming of the 'wild'. It also implies a young garden, or perhaps a recent nation-state.

Drawing on my experience of moving through the Global Cities exhibition (London 2007), I add the category of movement to the exhibition's categories of size, speed, form, density and diversity to argue that movement is at the core of the individual's experience of an environment. Next, using the categories of size, speed, form, density, diversity and my addition of movement, I analyse Body Maps to show how accessing certain elements of geography studies to focus on the movement of the body in a practice-based research project is an effective strategy to examine the choreography of an individual's embodied experience of both apartheid and post-apartheid South Africa. Belinda Dodson (2000: 148) warns against ignoring or accepting the geography of apartheid, such as urban and rural planning, and notes that "this is a geography that continues to pervade our everyday lives, constraining and frustrating the creation of post-apartheid cultural forms, practices, places, and spaces." The physical artefacts of apartheid South Africa remain reflected in the affluent suburbs, the management of agricultural land, and the availability of services in respective communities. This is not to imply that there has been no physical transformation, as this would ignore the many developments that have occurred since the dismantling of apartheid, for example, the construction of new housing and the development programmes in previously sidelined communities.

Despite these transformations, there remain many South Africans who have not benefited from the removal of the apartheid regime, and it is extremely unfortunate that the current 
climate of crime and corruption has severely limited the removal of social divisions and the positive integration of previously divided South African communities that make up this cultural geographic landscape. There are, of course, major differences between apartheid and post-apartheid South Africa, but it is dangerous to simply accept that the removal of apartheid legislation resulted in a South African society that can be succinctly described as a society that exists after apartheid, thus providing a neat and tidy taxonomy. Apartheid still has very real physical and cultural effects on contemporary South African society. According to Murray, "it is not surprising that the spatial separations, racial divisions, and structural imbalances that characterized the apartheid city have insinuated themselves into the post-apartheid cityscape and its representational forms" (2008: 11). Similarly, Dodson (2000: 148) argues that a "true understanding of the cultural [and racial] geography of apartheid demands an interpretation of what [Peter] Jackson (1989) calls 'maps of meaning'2: not the material forms themselves but what places meant to people and what people did in them." I argue that focusing on the movement of the dancer's body in space offers an effective strategy in investigating these 'maps of meaning.' Ann Daly (2000:191), writing about Ralph Lemon's dance project Geography (1997), states that dance "is an attempt to re-map theatre and what makes it visible." Daly (2000: 191-194) describes how choreography explores and describes "the space between here and there, the space between call and response, and the space between inside the body and out. [...] Space is the medium of exchange between dancers, between cultures, between performer and audience, between secular and sacred." I maintain that the performance area has a fluid boundary with the space outside its borders, and of course, the dancer's body on and off the stage, and it is vital that this relationship between the movement of the body on stage and the movement of the body off stage on the urban streets, or on the dusty rural paths, is considered especially in light of the apartheid and post-apartheid mapping of the South African landscape as "without our bodies we would have no geography" (Rodaway 1994: 31). Therefore, this article adopts aspects of geography studies as a framework - a map to analyse the choreography of an individual's embodied experience on the theatre stage. 
The politics of movement: geographical categories in a gallery space and on a theatre stage

In June 2007 I visited the Global Cities exhibition in the Turbine Hall of London's Tate Modern. Global Cities, according to Nicholas Serota in the Information Booklet, "takes inspiration from the effects of architecture and urbanism on our contemporary world, through the exhibition's focus on the ever-changing cultural, social and economic forces." I began the exhibition on Level Two (Walk Way), high above the display of photographs, scale models, enclosed boxed rooms for video installations, and other geographical data. It is from this Level Two vantage point that I spotted a massive satellite photograph of Johannesburg. ${ }^{3}$ I rushed down the staircase and stood in front of the satellite photograph that maps the city. Johannesburg featured as one of the ten cities that the exhibition focused on, concentrating on their "social and spatial conditions" (Information Booklet). Global Cities organised the selected cities, ranging from Cairo to Tokyo, and related artwork into five general categories - size, speed, form, density and diversity. ${ }^{4}$ Johannesburg (and related artwork) appeared in the form and diversity categories. The satellite photograph of Johannesburg was a good example of how South Africa was geographically organised according to apartheid policy. This was evident in the uneven but distinctive patterns of the rooftops and access roads; for example, townships' sites with their tightly packed rooftops organised in avenues with the haphazard nature of the informal settlement are in marked contrast to the neat and tidy grid plans of the previously 'white' suburbs. Major road networks snaked in and out of the various spaces swallowing and spitting out the industrial areas with their brightly painted buildings. The satellite photograph of Johannesburg further raised my awareness of the post-apartheid situation, where "[t]he pattern of socially, economically and spatially segregated cities remains, with its attendant problems of lengthy and expensive commutes for the poor, and growing areas suffering from social exclusion, growing poverty, ill health and crime" (Harrison, Todes \& Watson 2008: 12).

However, it was looking at this photograph, where my eye was freely able to wander, that it occurred to me that perhaps movement should be included in the exhibition's set of categories, for instance, the quality of movement between various areas of the city by those that live in and out of that particular city. During apartheid certain areas would be difficult to move into and through because of legislation. Post-apartheid, movement should be available to all, but various influences such as economics or crime have resulted in 
people moving in and out of areas, or not moving through certain areas at particular times. In general, the exhibition did not notice the effect movement has on those that live in various cities, and although it points to "arduous journeys to work on informal public transport systems (a reference to Johannesburg in the Information Booklet), the exhibition failed to acknowledge the crucial role movement plays in the shaping of the categories of size, speed, form, density and diversity.

Movement is "the human condition" (Oguibe 1997: 11) and this related to all of the exhibition's categories. ${ }^{5}$ This exhibition did not include movement as a separate category, despite the fact that it was movement that functioned as a through-line - a highway clearly moving through and connecting the categories mentioned and highlighting the relationship between the body and the urban environment. Movement is at the core of the individual's experience of the environment. It was through my moving body that I experienced both the urban landscape and the art exhibition. I was able to move freely through the exhibition space, choosing where I wanted to go and what I wanted to look at without much interference. I was able to look at photographs of São Paulo and Istanbul places I have as yet not moved to and through because of social and economic factors. There in the Tate Modern I was able to move around the models of density, for instance, of the cities of Mumbai and London. I was able to move and look at the cities from above due to satellite photography. I was able to move to various artworks that relate to the cities. With my index finger, I could trace both real and imagined journeys on the satellite photograph of Johannesburg, going in and out of areas I have and have not physically moved through.

Movement, and the other categories of Global Cities - size, speed, form, density and diversity - are important organising principles for thinking about the geography of the urban environment, but also for thinking about the movement of the South African dancer's body. I use a composite of these categories in this article precisely to illustrate the links between the geography of the South African urban environment and the South African dancer's body. Geographical knowledge systems, like mapping and its spatial pathways, share areas of interest with dance, and I survey these areas of concern and underline that because of the history of the body and space in South Africa, dance is acutely aware of this relationship and therefore well-equipped to stage the bodily experience of space. 
Size in general geographic terms relates to population and physical area - the number of people and the size of the place. For example, Johannesburg is far bigger in size in comparison to Durban, where I worked on Body Maps. In dance, the category of size manifests when thinking about the number of dancers, the dimensions of the performance area, and the range the dancers' movements explore in and around their bodies. Size also refers to the magnitude of the movement, for instance a small gesture, such as the flick of a wrist, or a grand movement where a dancer jumps and is suspended in the air by a fellow dancer. The dimensions of the performance area, the size of the dancer's movement and the size of the space that the dancer explores are obviously an important concern when choreographing and these various factors are examined in this article. The dancer's exploration of space - and the extent of the exploration - is critical when considering how, during the apartheid era, bodies were legally limited in their freedom of movement because of 'racial' categorisation. In light of the above, and with the effect the current climate of crime has on the South African body in the post-apartheid period, it is critical that there is a discussion of the dancer's exploration of the performance space in Body Maps as this discussion throws light on the individual South African body and its experience of the South African landscape, and in this case due to the practice-based research project's focal point, the urban environment.

The project employed two young adult dancers: a 'white' female dancer, Shayna de Kock, and a 'black' male dancer, Mduduzi Ntuli. In the opening section de Kock entered walking with a toy flowerpot balanced on her head as if she was walking on a catwalk, thus hinting at how the female body is displayed and the carefully mapped-out route young women - of all 'races' - must follow in contemporary South Africa. Walking off this path might result in danger - whether real or imagined. De Kock was laden with a yellow plastic watering can stuffed with a bouquet of plastic flowers, and a shopping bag containing more plastic flowers, plastic dolls, gardening gloves, plastic wind-up birds and a flower-arranging structural base. Without unbalancing the toy flowerpot, she moved to the middle of the stage where a microphone stand decorated with Hindu Temple textile flower garlands was positioned. She was choreographed to perform her entrance in such a way so that the focus would be predominantly on her entrance and her movement despite the fact that Ntuli, a 'black' male dancer, was standing still on the stage all this time. Ntuli's stillness emphasised how his range of movement was governed by apartheid policies; his right to movement was oppressed by the apartheid regime. As a 'white' South African, de Kock has far greater movement possibilities than Ntuli as a 'black' South African. 
Nevertheless, de Kock and Ntuli are not performing in isolation from each other. They are connected as they share the performance space much like all 'races' share the South African landscape. The crucial issue here is that apartheid privileged 'white' South Africans and limited 'black' and other 'racial' groups in terms of their freedom of movement, as illustrated by de Kock's authority over the performance space and Ntuli's fixed movement. Hence the landscape of apartheid South Africa was not shared equally amongst the 'racial' groups and the majority group of 'black' South Africans had their movement possibilities governed by apartheid practices like the Pass Book.

In the performance of Body Maps de Kock proceeded to read out from a geography school textbook entitled Mapwork Made Easy (Blackbeard 1992). This textbook advises the teacher that the 'book cannot replace a theory textbook. The students' theoretical knowledge is essential, especially when dealing with interpretation. This is particularly important when dealing with the South African landscape where the socio-political history of this country has affected so many aspects of human geography" (1992: v); the necessary emphasis on the embodied experience of the South African environment that South African dance is aptly suited to explore and represent theatrically. The text de Kock read out, though, consisted of advice or directions for aspiring gardeners, which was workshopped in rehearsal, but included the topics offered by the geography textbook - the map code, scale, area, gradient and direction.

Urban garden spaces were discussed in the rehearsal process as these garden spaces are landscaped by those that use them and reflect on those South African bodies whether intentional or not. The performers and I have significant experience of these outside spaces and therefore used this as a basis for a performance experiment that explores the shared aims between South African dance and geography, especially in relation to the embodied experience of urban South Africa. De Kock followed the directions advised to aspiring gardeners and built an arrangement out of the plastic materials that resembled a garden of sorts. This section of Body Maps was partly choreographed and partly improvised. De Kock was not tightly bound to any particular gesture or range of movement. She could, with freedom, use any gesture whilst making her garden arrangement to her own design. And, with the strategy of her amplified voice, assortment of plastic materials, and centre-position, de Kock dominated the opening section alluding to the domination of the South African urban environment by 'white' South Africans. De 
Kock's performance alludes to the 'white' South African privilege of having an ornamental garden, and also, how this is a leisure pursuit as illustrated by de Kock's casual manner in creating on stage the plastic ornamental garden.

In contrast, Ntuli's movements were severely limited and this suggests a body that is regulated by industry: it is a disciplined body that labours without leisure. Ntuli began the opening standing on an $X^{6}$ taped onto the performance area's floor. Throughout the dance piece, Ntuli would move directly from $X$ to $X$ following a carefully planned pathway. Whilst standing on the first $X$ in the opening, he slowly moved his focus from where de Kock was standing in a straight line along the floor to his $X$ and then slowly up his body. This level of intense focus and eye-control occurred throughout the choreography. De Kock had freedom in the size of her gestural movement whereas Ntuli, like many 'black' South Africans during apartheid, had his movement shape and size controlled by an outsider, in this case, by the choreographer, and during apartheid, by the state and its legislation. Yet, Ntuli was able, if he wished, to disobey by slightly increasing his range of movement, as a consequence reflecting the many South Africans who disobeyed and burnt their Pass Books, thus suggesting agency available to the individual, sometimes at a cost, of course.

Another instance in Body Maps when the size of Ntuli's spatial movement was restricted was when Ntuli performed the first set of his elevations. He jumped into the air three times in succession, attempting to jump as high as he was physically able. His use of space was regulated, as he had to imagine that he was jumping between two tightly built high parallel walls. This resulted in Ntuli keeping his arms and hands as close as possible to his sides, pointing his feet, and keeping his chin parallel to the ground. This act of landing and jumping had to be precise. This is an uncomfortable and difficult way to perform a high jump since if a dancer is required to make great height in a perpendicular jump, they are reliant on the maximum use of their arms and legs. For instance, the performer bends their knees as low as possible making use of this resistance from the floor to jump higher. By pushing down with the arms in a resistant manner, the back muscles are activated which help to make further height. Instead, in Body Maps Ntuli was unable to make great use of his legs and arms to make height due to the choreographed restrictions on his body: his hands and arms had to remain close to his sides.

A further limitation placed on Ntuli's range of spatial movement in the performance of Body Maps occurred when Ntuli ran across the stage from his first $X$ to his second $X$. He had to 
make a direct approach and execute a sudden stop when he reached the second $X$, as if a high wall prevented him from going further. Here Ntuli repeated the three jumps under the same circumstances as previously described. During Ntuli's dash and three jumps, de Kock casually moved without restriction making her plastic garden arrangement. De Kock, if she wished, was 'free' to ignore any of the instructions that the guide offered. The movement contrast between the performers emphasised the individual's bodily experience of space and how apartheid legislation attempted to rule and choreograph the 'racial' body in a 'racialised' space.

Speed as a category is introduced in the Tate Modern exhibition as the rate of urban growth. Urbanisation has drastically increased over the last few decades in South Africa with not only South Africans moving to the cities, but immigrants from other African countries too, looking for employment and better opportunities, rapidly making their way to urban centres like Johannesburg and Durban. The high rate of urbanisation and migration internally in Africa has led to conflict amongst fellow Africans unfortunately. ${ }^{7}$ The chief operating officer of the Social Development Department (in South Africa), Zane Dangor, claims that "increased rural-to-urban migration attest[s] to the poverty in rural areas", and "the government should make rural areas more attractive as places where people could live decent lives" (Unknown 2007). However, the executive director of the United Nations Population Fund, Thoraya Ahmed Obaid, proposes that "[w]e must abandon a mindset that resists urbanisation and act now to begin a concerted global effort to help cities unleash their potential to spur economic growth and solve social problems". This relationship between rural and urban areas - and the movement between them - has been and remains a constant source of debate, ${ }^{8}$ but what is relevant to this article's argument is how the choreography in South African dance uses varying speed of movement, how this is employed, and how the rate of movement by a performer is able to represent or stimulate debate on the speed of social movement by South African bodies.

Jennifer Robinson (2004: 161) calls attention to how in South Africa the city has been a "key site in the political struggle against apartheid," and "currently a site of hope for emancipation from poverty", and how the 'black' African presence in cities was feared by apartheid perpetrators. Robinson (2004: 161) does not ignore the complexity of the urban 


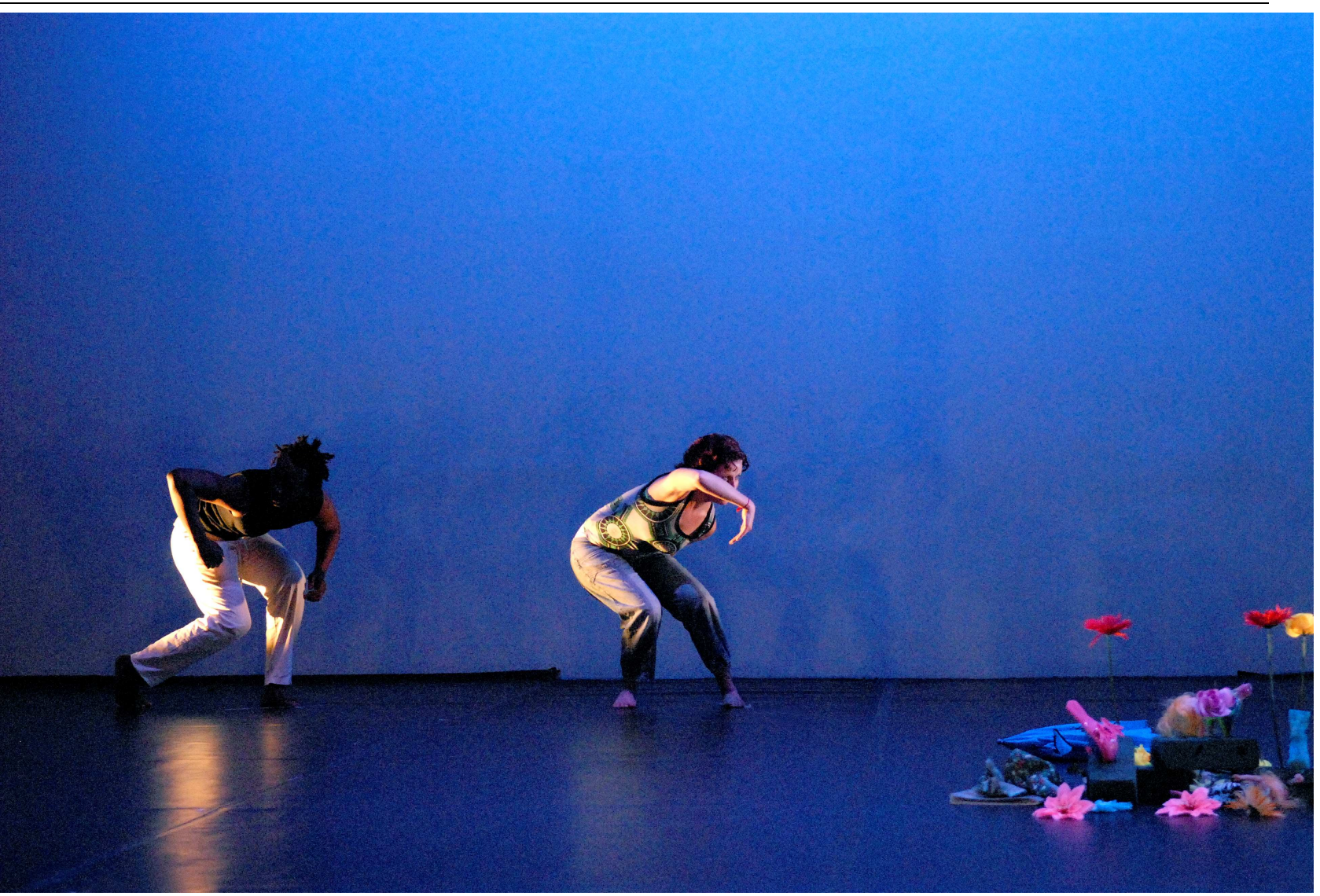

Photo 1 - Still from Body Maps

space as "sites and sources of oppression, exclusion, and impoverishment", but she argues that in contemporary South Africa the city has the potential to "feed into and support revolutionary and transformative moments". I support Robinson's argument as it further demonstrates the ambivalence of the city and its effect on the South African experience (2004: 162), and uncovers the unequal power relationships amongst the 'racial' groups of South Africa.

In Body Maps de Kock governs her own rate of movement, unlike Ntuli, who has to follow a disciplined timing system. Later in the performance both performers move together from taped $X$ to $X$, yet although they are moving together, they are definitely not moving together precisely in time. After watching recordings of rehearsals and the final performance of Body Maps, it is noticeable that Ntuli jumps higher than de Kock, and the positioning of de Kock's $X$ requires her to run slightly further than Ntuli. They can never be in complete perfect time, as the landscape of the performance area requires the performers to travel at varying rates. This discovery demonstrates that despite apartheid legislation governing movement, and the effects crime and urbanisation have on postapartheid South Africans, our understanding of speed is unique to our bodily experience 
and the demands of the landscape are specific to the individual South African body. Even in the closing moments of Body Maps after Ntuli and de Kock have sped across the stage to their final Xs, their respective tempos when moving through a martial-arts-like motif which places an emphasis on the breath and simultaneous partner movement are never precisely in time, and shall never be, no matter how hard they work to achieve this - in rehearsal and in performance.

Bodily experience of time is distinctive to each body, much like the experience of urbanisation or travel is unique to each South African. Even so, despite this pessimistic view of the performers' experience, some claims can and must be made for group experience. De Kock and Ntuli form and are members of a community as they share the communal experience of rehearsal and performance in regards to this project, as dancers, and as young South Africans. The choreographic demand for simultaneous movement and the fact that the dancers were required to have the same rate of breathing serve as a reminder of the geography that South Africans share, and that South African dance is so well-suited to explore our relationship to each other and the landscape. This example illustrates how South African choreography is able to uncover the ambivalence of the urban environment and its effect on the South African experience.

Form pertains to the shape of the space, and in the Global Cities programme it describes how the satellite photographs in the exhibition "illustrate the diversity and complexity of human impact on these cities, as physically manifest in street widths, block and plot sizes and distribution of open green space" (Information Booklet). The exhibition touches upon how in South Africa "attempts to dismantle the social and spatial legacy of apartheid are underway, but elements of an unjust geography are resurfacing" (Information Booklet) because of factors such as crime and informal settlements. If these factors can affect the spatial layout, how might they affect the South African body and the form this representation takes on stage? In Body Maps what shape does the moving body take on stage?

"People make sense of their world by connecting and separating things, by drawing distinctions and ordering relations, and these processes leave their mark in space" (Tonkiss 2005: 30). In South African dance the space is divided up and organised by the movement patterns of the dancers. This is easily recognised in the difference between the spatial use of solo and partnering work, or in performers executing the same movement 
motifs; different bodies fix space in different ways. Choreographers are acutely aware of how the body produces and composes space; hence South African dance is well suited to explore the relationship South Africans have with their surrounding space. There are two distinct formations of space devised by Ntuli and de Kock as they move on stage in Body Maps. Ntuli carves the space up into definite shapes as he moves from $X$ to $X$ whereas de Kock can improvise in (and with) the space. Through choreographed movements, the dancers' pathways reflect the South African experience of apartheid space. De Kock was less limited in terms of her movement patterns than Ntuli due to her 'race.'

In one section of Body Maps Ntuli moves to an X on the apron of the stage. Though dated, the text Space for Dance: An Architectural Design Guide (1984: 29) states that the apron of the stage functions as an "empty space [that] may create an esthetic gulf between audience and dancers." The apartheid state managed a complex system of spaces and gulfs between spaces. 'White spaces' and 'black spaces' remained separate through geographical devices such as empty tracts of land termed 'buffer zones' which were regulated spaces between the 'racial' areas declared for different 'racial' groups (Shepherd \& Murray 2007: 6). It is into this no-man's land that Ntuli steps as he moves to stand on the apron of the theatre's stage.

Ntuli carves up the space through a slow martial art-like performance of a contemporary interpretation - a re-configuring - of a Zulu warrior step and classical Indian dance. Instead of keeping the lifting leg's position in front of the body, Ntuli is choreographed to open his leg out high to the side. This is done extremely slowly with particular attention paid to the pathway of this movement and its effect on other parts of the body - how this movement of the limb opens out his pelvis, how his foot is flexed showing his sole, how he resists the pull of gravity thus working with the idea of tension and release through the body, and how his fixed leg provides the support for this movement and by pulling up through this leg he is able to maintain and support the height of his moving leg.

When Ntuli - after holding the open position with his leg high and his hands palms out to the audience for what seems a very long time requiring a marked degree of effort and stamina - releases the position and folds to the floor, there is a loud intake of breath from the audience. Ntuli leaning over waits as de Kock walks slowly towards him moving into this no-mans land of the apron of the theatre's stage. Ntuli and de Kock meet in and share this space as de Kock rolls over Ntuli's back. She does this with care and he supports her 


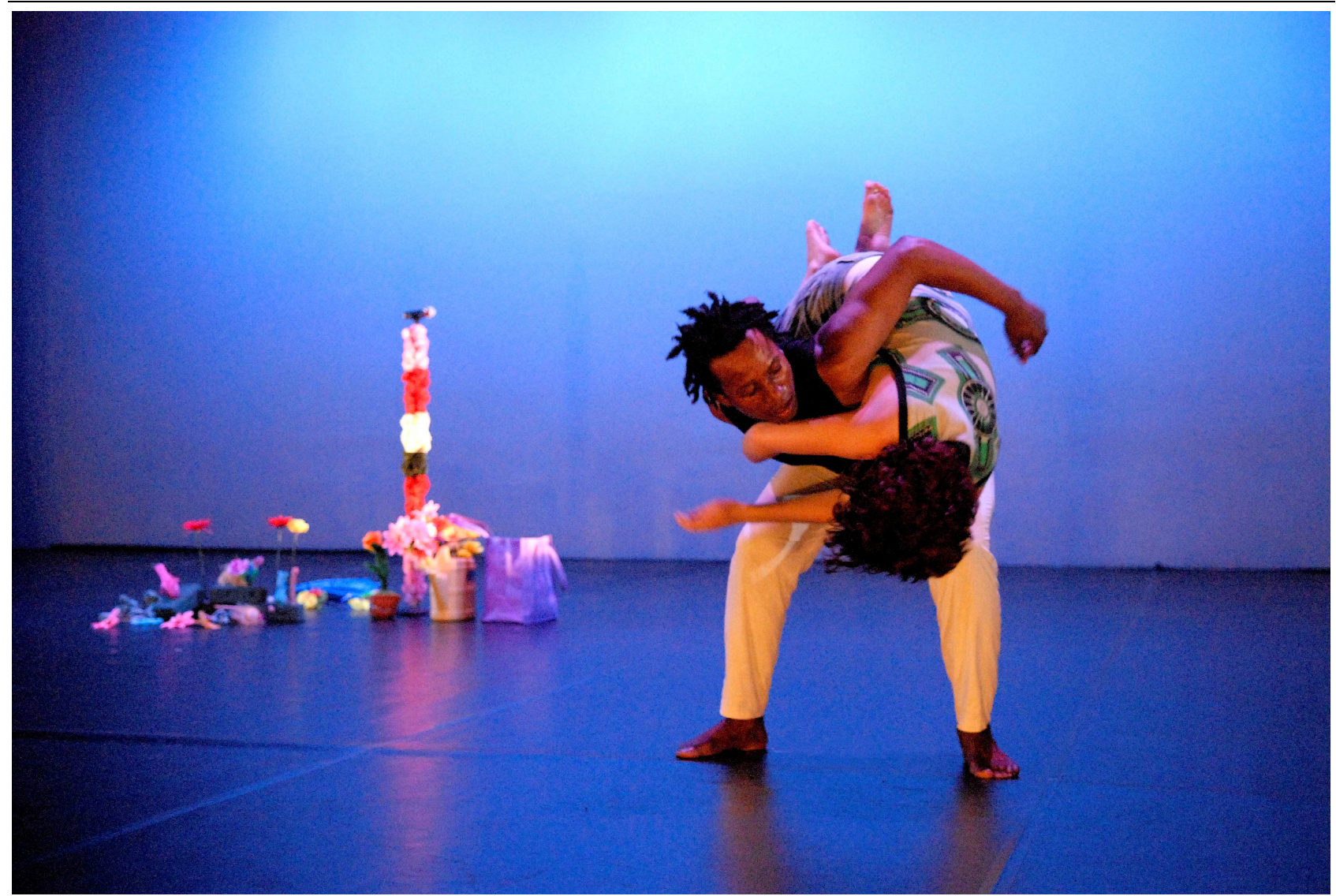

Photo 2 - Still from Body Maps

and assists her in her movement. In this no-man's land the dancers form a community, a 'grey' area. It is a grey area like the communities of Sophiatown and District Six, which the apartheid government removed with force, and it is a 'grey' area such as the Grange in Pietermaritzburg and the Berea in Durban, which developed as a result of the repeal of the Group Areas Act in 1991. This section of Body Maps with its spatial arrangement, Ntuli's and de Kock's sharing of the space, and the dancers' supportive mode of working together, illustrates both the possibility and the actuality of 'black' and 'white' South African bodies working together in the South African urban environment. What is of concern is the power relationships that are at play in this urban environment: what is the share or ratio of power in this relationship and how is this measured? An analysis of the density of this space and its uses unearths the embedded power relationships at play in the South African urban environment and in Body Maps.

Hugh Wenban (2006: 1-16) proposes that density is as important as size in terms of urban economics. Density describes the "number of people living in a given area" (Information Booklet) and is therefore associated with housing, infrastructure, and living standards. For instance, consider the difference between a South African experiencing living in an 
overcrowded shack settlement and another citizen living in the city suburbs. Density is equally an important factor in the choreography of South African dance, for example, working out the number of times a gesture is to be repeated, or, how many performers are to execute a specific pathway across the performance area. Focusing on density in South African dance, I theorise on how South African dance demonstrates the South African experience of the density of the space by using gesture as a metaphor.

Focusing on the quality of flow of the movement, Ntuli's movement appears constricted or bound, and even when he is racing across the stage, his movement action seems capable of being stopped suddenly, and on some occasions during Body Maps Ntuli's movement is held as if he is oppressed and restricted in the space. There is an impression of claustrophobia surrounding his movement, and this performance and his experience of flow is in contrast to de Kock's free movement as she reads and designs and constructs her own garden out of plastic materials by the microphone stand. This performance of flow by the performers hints at the individual body's experience of the density of the space in which they move. De Kock's environment is not nearly as crowded as Ntuli's appears to be thus metaphorically reflecting the apartheid and post-apartheid experience of density where de Kock's 'race' would have had - and still does have - better access to housing and services unlike the other 'racial' groups. Apartheid privileged 'white' South Africans and its effects benefit 'white' South Africans post-apartheid. It is rare for 'white' South Africans to find themselves living in shacks with no access to running water; it is deplorably still common - and this condition is deteriorating - for South Africans of the other 'racial' groups to form the majority of those living as shack dwellers or in areas that have limited access to services.

The impression of claustrophobia or spatial restriction as suggested by Ntuli's movement in Body Maps is not limited to the specific areas, of previous apartheid-engineered homelands, and the informal housing settlements of the shack dwellers. This claustrophobia manifests itself in the increase of gated communities, and the constant monitoring of journeys, be these journeys by car, bus, train, or foot, due to the threat or real event of crime. Currently South Africans are trapped in their homes, transport modes, and experience the South African environment as compact in order to be able to efficiently monitor and survey the borders of their surrounding space. This compartmentalisation of the space was represented in the final moments of Body Maps as Ntuli and de Kock together perform a sequence where they raise and lower their arms and legs in a motif 
facilitated through their connection to their breath. Even though Ntuli and de Kock are attempting to perform this simultaneously, they divide their surrounding space into manageable components and are further separated from each other and the audience.

Throughout Body Maps there is no music or sound besides de Kock's gardening instructions and Ntuli's controlled breathing patterns choreographed to coincide with his constructed movements. As a result of the absence of recorded music and sound, at times, the sound of the space being carved up by the performers is audible. In fact, the performance was choreographed without music or other accompaniment in order to accentuate the mechanism of the moving body and its movement through space to the audience. And in light of the history of the 'racial' body in South Africa, this movement through space and the form it takes in either co-operation or deviation is unique to each subject thus highlighting the individual agency available or unavailable to the subject.

A performer's kinesphere is shaped not only by his/her body size, but also because of the intersection of gender, 'race', and nationality in some respect - "obviously, ways of holding the body, gesturing, moving in relation to time and using space (taking a lot, using a little, moving with large sweeping motions, or small contained ones, and so forth) all differ radically across various social and cultural groups and through time" (Desmond 1997: 33). Diversity in South African dance refers to the variety of performance forms, media, performers, and body types that are utilised in this art practice. For example, South African contemporary dance draws on Euro-American contemporary dance training, South African traditional dance, Indian classical dance, and popular dance forms like the isipantsula amongst others. Choreographically, there is a wider range of body types and a limited access to professional training in South African dance if compared to Euro-American contemporary dance. Geographically, "in an urban context, diversity - the level of variety within a city - is usually interpreted as its ethnic and racial composition [...] the spread of ages and incomes, education levels, the range of employment sectors, and people born in the city versus newcomers" (Information Booklet) and is related to the demographic of South Africa. ${ }^{9}$

Iris Marion Young, in her insightful essay "Throwing like a girl: a phenomenology of feminine body compartment, motility, and spatiality" (2005: 43), emphasises how women learn to actively hamper their movements as they come to understand they are girls and how women live under the threat of invasion of their body space; the extreme form of this 
threat is rape, but women are 'daily subject to the possibility of bodily invasion in many far more subtle ways as well' (2005: 45). Despite gender-sensitive legislation, many South African women share this threat and this is unfortunately a very real threat. This threat is not limited to women as men also undergo invasion not only due to sexual criminal activities, but like women, because of other criminal activities that place the body and its surrounding space under threat. Therefore, by focusing on how performers understand and explore their kinespheres in a performance work, and the diversity of this event, I am able to gain insight and reflect on the experiences of the individual South African body in space.

De Kock as a female South African undergoes this threat of invasion in her life off the stage and so too does Ntuli, and this common and unfortunate experience is demonstrated in Body Maps. As discussed earlier in this article, in the opening section de Kock is able to design her garden and decide whether to obey the Mapwork Made Easy textbook's instructions, thus reflecting her greater freedom of movement if compared to Ntuli's under the apartheid regime. Later de Kock joins Ntuli and both performers move together from $X$ to $X$, and perform a motif that requires them to explore the space directly surrounding their bodies: their kinesphere. Ntuli's exploration of his kinesphere remains limited and restrained even when de Kock joins him, and this and de Kock's now restrained performance, I conclude, further validates why in post-apartheid South Africa the struggle for the freedom of movement remains a necessary and urgent issue, and why South African dance, because of the history and geography of the body in South Africa, is decidedly articulate about embodied spatial experience.

\section{Moving towards a conclusion}

Movement transfers, travels, traffics and interchanges, and these gestures and actions of movement are directly related to my practice-based research project; there is the traffic of bodies when de Kock and Ntuli pass each other in the performance of Body Maps. Ntuli travels from one side of the stage to the other as he runs. He moves between the air and the floor as he makes three high jumps. De Kock interchanges her weight from the ball of her right foot to her left as she rolls over Ntuli transferring her weight. Movement is at the core of South African dance and for many scholars and practitioners, at the core of human experience: even when standing still, the body is moving - cells, heart, blood, lungs, 
breath, the globe, the universe - all in motion. The human body is designed for force absorption and force propulsion. Its purpose is to move!

Standing in front of Kendell Geers's wall of photographs of the front gates and partitions of South African suburban homes in the Global Cities exhibition, I was further reminded of the importance of movement. Entitled Suburbia (1999), Geers's photographs highlighted the role crime plays in the geography of South Africa, and how crime hinders the pathways of movement through post-apartheid South Africa. The photographs displayed a variety of front gates, garage doors, and high walls of suburban homes which I identified as common to the suburbs of Johannesburg - I recognised a wall that is round the corner from my partner's parents' house in Johannesburg. There are signs fixed onto these walls and gates advertising various security firms, a few depicting guns or fierce dogs that are hired to protect these family homes. Some walls had broken glass or barbed wire on the top to prevent criminals climbing over. These frontages resembled fortresses or prisons, and here there was an attempt to control the movement of bodies in and out of these spaces.

Movement as a value and practice is extremely important in the South African context. Firstly, the passage of peoples was one of the conditions of colonialism and migration. Secondly, this practice was not neutral; as it had both positive and negative consequences, for example, land loss and acquisition. "Forced removals, evictions from ancestral homes, and the active destruction and re-invention of neighbourhoods and communities are just some ways that geographical processes were experienced by South Africans living under apartheid" (Elder 1998: 153) and colonialism. The historical apartheid assignment of 'racial' bodies to 'racial' spaces makes South Africa a compelling and evocative site for investigation into the relationship between bodies and geography, especially with regards to movement. During apartheid, legislation governed traffic by specific 'races' in and out of 'racial' spaces. Even so, it would be simplistic to ignore the intersection of 'racial' categories with economics and capital. David M. Smith (1992: 314) highlights how the "urban landscape of group areas was thus not only segregated by race but also sharply differentiated according to housing and neighbourhood quality, availability of service and access to work."

Smith (1992: 316) develops his outlook on post-apartheid cities and states that class divisions will augment the 'racial' separation of those living and working in the urban areas thus producing cities of 'deracialized apartheid.' Over a decade since his conclusion was 
published, the effect of economics and class is evident in a survey of urban areas. Though his prediction of which 'racial' groups moving in and out of apartheid segregated areas was short-sighted - he privileged 'racial' factors over access to capital (1992: 315) - former working class/lower middle class areas appear far more integrated than those of lower and upper class areas. Once again, it is necessary to acknowledge the intersection and the ever-changing hierarchy of these discourses and practices and their resulting effects on the South African landscape and the South African body.

This highlights how "the apartheid map is not a coincidental collection of incidental spatial representations. Rather the map is the product of a complicated and nuanced reconfiguring of socio-spatial relations - racial identities invented by inscribing them in space" (Elder 1998: 154). Therefore, movement by South African bodies in and out of and through space underwent an oppressive type of legislative choreography. ${ }^{10}$ Freedom of movement is fundamentally important. The Freedom Charter of 1955 and the Bill of Rights for a New South Africa of 1993 include the right of movement by South Africans without discrimination (Asmal 2005: 62, 99). ${ }^{11}$ Regretfully this freedom has yet to be achieved and has come under greater threat because of factors such as the increase of crime in the country over the last few years. Hannah Le Roux (1997: 43) highlights how "[c]rime makes it risky to maintain a presence in the city." In addition, I hold that many of our contemporary struggles exist because freedom of movement is limited due to the role economics and nationality - who holds what passport and what funds - play in the freedom of movement. South Africans and the category of movement, despite the repeal of apartheid legislation that governed movement, remains at present controlled. 


\section{Notes}

1) I place 'racial' categories in inverted commas throughout this article to make the reader aware of the artificiality of 'race' as a concept, and how this apartheid categorisation had very real effects on the South African body - then and now in the early stages of the twenty-first century. For a brief breakdown of the term 'race' in South Africa, see Erasmus (2008).

2) See Jackson (1992).

3) For an overview of Johannesburg in terms of its history and sociology, see Mabin (2007).

4) These categories were never distinctly defined in the exhibition, and in my analysis of my practicebased project, my aim was not to succinctly define these terms. Rather, I was interested in surveying how dance studies and geography studies have much in common, and how this combined focus highlights an individual experience of the South African urban environment. This article addresses the research processes and their consequences; my primary motive is to survey how aspects of geography studies could be employed as tools to analyse the choreography of a South African individual's embodied experience both on and off the stage.

5) Oguibe (1997:112) states that Africa extends beyond its cartographic borders and has become a "referent for many who reside within multiple borders, those who carry the continent but not the landmass with them", like myself.

6) I credit Clare Craighead of Flatfoot Dance Company for the idea of taping the $X$ to the stage floor.

7) See Unknown (2008).

8) South Africa is a country of perpetual urbanisation. See Lemon (2000) for a concise history of urbanisation in South Africa.

9) See Zuberi et al. (2005) for detailed analysis of the demographic make-up of South Africa and research into 'racial' classification and migration.

10) See Koloane (1997), who refers to the removals of peoples from their ancestral lands as 'absurd chessboard choreography' (32).

11) The Freedom Charter (1955) and the Bill of Rights for a New South Africa (1993) also include the right to land as a fundamental birthright. 


\section{References}

ARMSTRONG, L.; A.I.A.; MORGAN, R. 1984. Space for Dance: An Architectural Design Guide. Lipske, M. (Ed.). Publishing Center for Cultural Resources: United States of America.

ASMAL, K. (Ed). With CHIDESTER, D.; LUBISI, C. Legacy of Freedom: The ANC's Human Rights Tradition. Johannesburg and Cape Town: Jonathan Ball.

BARRETT, E.; BOLT, B. (Eds) 2007. Practice as Research: Approaches to Creative Arts Enquiry. I. B. Taurus.

BIALAS, Z. 1997. Mapping Wild Gardens: The Symbolic Conquest of South Africa Essen: Die Blaue Eule.

BLACKBEARD, A. D. 1992. Mapwork Made Easy: A Handbook for Geography Students Standards 8 to 10. Pietermaritzburg: Heinemann-Centaur.

BUTTERWORTH, J., and WILDSCHUT, L. 2009. General Introduction: Studying Contemporary Choreography. In: Butterworth, J.; Wildschut, L. (Eds.). Contemporary Choreography: A Critical Reader. London and New York: Routledge, 1 - 3.

DALY, A. 2000. Afterword. In: Lemon, R. Geography: Art/Race/Exile. Performance Text by Tracie Morris. Hanover and London: Wesleyan University Press, 191 - 197.

DESMOND, J. C. 1997. Embodying Difference: Issues in Dance and Cultural Studies. In: Desmond, J. C. (Ed.). Meaning in Motion: New Cultural Studies of Dance. Durham and London: Duke University Press, 29 - 54.

DODSON, B. 2000. Dismantling Dystopia: New Cultural Geography for a New South Africa. In: Fox, R; Rowntree, K. (Eds) The Geography of South Africa in a Changing World. Cape Town and Oxford: Oxford University Press, $138-157$.

ELDER, G. S. 1998. The South African Body Politic: Space, Race and Heterosexuality. In: Nast, H. J.; Pile, S. (Eds). Places Through the Body. London and New York: Routledge, 153 - 164.

ERASMUS, Z. 2008. 'Race'. In: New South African Keywords. Edited by Nick Shepherd and Steven Robins. Johannesburg: Jacana; Athens, Ohio: Ohio University Press, 169 - 181.

FOX, R., and, ROWNTREE, K. 2000. Introduction. In: Fox, R; Rowntree, K. (Eds) The Geography of South Africa in a Changing World. Cape Town and Oxford: Oxford University Press, 1 - 5.

HARRISON, P., TODES, A., and WATSON, V. 2008. Planning and Transformation: Learning from the PostApartheid Experience. London and New York: Routledge.

HOLLOWAY, L., and, HUBBARD, P. 2001. People and Place: The Extraordinary Geographies of Everyday Life. Harlow, Essex: Pearson Education.

INFORMATION BOOKLET. 2007. Global Cities.

JACKSON, P. 1992. Maps of Meaning: An Introduction to Cultural Geography. London and New York: Routledge.

KOLOANE, D. 1997. Walking the Tightrope. In: Trade Routes: History and Geography. $2^{\text {nd }}$ Johannesburg Biennale 1997. Matthew DeBord and Rory Bester (Eds). Johannesburg: Greater Johannesburg Metropolitan Council; Den Hag: Prince Claus Fund for Culture and Development, 32 - 35.

LE ROUX, H. 1997. Contingency Plans. In: DeBord, M.; Bester, R. Trade Routes: History and Geography. $2^{\text {nd }}$ Johannesburg Biennale 1997. Johannesburg: Greater Johannesburg Metropolitan Council; Den Hag: Prince Claus Fund for Culture and Development, 43 - 45.

LEMON, A. 2000. Urbanization and Urban Forms. In: The Geography of South Africa in a Changing World. Roddy Fox and Kate Rowntree (Eds). Cape Town and Oxford: Oxford University Press, 186 - 210.

MABIN, A. 2007. Johannesburg: (South) Africa's Aspirant Global City. In: The Making of Global City Regions: Johannesburg, Mumbai/Bombay, São Paulo, and Shanghai. Edited by Klaus Segbers with the assistance of Simon Raiser and Krister Volkmann. Baltimore: The Johns Hopkins University Press, $32-63$.

MURRAY, M. J. 2008. Taming the Disorderly City: The Spatial Landscape of Johannesburg after Apartheid. Ithaca and London: Cornell University Press.

NAST, H.J., and PILE, S. 1998. Introduction: MakingPlacesBodies. In: Nast, H. J.; Pile, S. Places Through the Body. London and New York: Routledge, 1 - 19.

OGUIBE, O. 1997. Time. Space. Movement. In: Cross/ing: Time. Space. Movement. Oguibe, O. with contribution by O. Enwezor. Catalogue for the Contemporary Art Museum: University of South Florida, $10-12$.

SMITH, D. M. 1992. Conclusion. In: Smith, D. M. (Ed.). The Apartheid City and Beyond: Urbanization and Social Change in South Africa. Johannesburg: Witwatersrand University Press; London and New York: Routledge, 314 - 317.

ROBINSON, J. 2004. The Urban Basis of Emancipation: Spatial Theory and the City in South African Politics. In: Lees, L. (Ed.). The Emancipatory City? Paradoxes and Possibilities. London, Thousand Oaks, and New Delhi: Sage, 161 - 177.

RODAWAY, P. 1994. Sensuous Geographies: Body, Sense and Place. London and New York: Routledge. 
SHEPHERD, N.; MURRAY, N. 2007. Introduction: Space, Memory and Identity in the Post-apartheid City. In: Murray, N.; Shepherd, N.; Hall, M. (Eds). Desire Lines: Space, Memory and ldentity in the Postapartheid City. London and New York: Routledge, 1 - 18 (p. 6), 1 - 18.

UNKNOWN. 2007. Govt: SA Cities Not Ready for Migration Patterns. http://www.mg.co.za/articlePage.aspx?articleid=312525\&area=/breaking_news/breaking_news_nati onal/ [accessed 28 June 2007].

UNKNOWN. $2008 . \quad$ Xenophobia: A 2 Special http://www.mg.co.za/specialreport.aspx?area+xenophobia_home [accessed 28 May 2008].

WENBAN-SMITH, H. 2006. Urban Infrastructure: Density Matters, Not Just Size. Research Papers in Environmental and Spatial Analysis. London School of Economics and Political Science, (104. February) $1-16$.

YOUNG, I. M. 2005. Throwing Like a Girl: A Phenomenology of Feminine Body Compartment, Motility, and Spatiality. In: Young, I. M. On Female Body Experience: 'Throwing like a Girl' and Other Essays. Oxford: Oxford University Press, 27 - 45.

ZUBERI, T., SIBANDA, A. and UDJO, E. (Eds). 2005. The Demography of South Africa. Armonk, New York, and London: M. E. Sharpe.

\section{Photographs Credit:}

Body Maps: or how our garden grows: Val Adamson and Centre for Creative Arts (University of KwaZulu-Natal)

\section{Acknowledgements:}

Thanks to all those who have reviewed and offered guidance in preparing this article. Thanks to those who attended the performance outcome of the practice-based research project, and of course, thank you to the dancers for their involvement and their discipline. 